\title{
Age, Growth and Mortality of Unio tigridis (Bourguignat, 1852)
}

\author{
Mehmet Fatih Can ${ }^{*}$, Hülya Şereflişan ${ }^{2}$ \\ ${ }^{1}$ Faculty of Marine Science and Technology, Iskenderun Technical University, Department of Water Resources Management and \\ Organization, TR-31040 Iskenderun/Hatay, Turkey. \\ ${ }^{2}$ Faculty of Marine Science and Technology, Department of Aquaculture, TR-31040 Iskenderun/Hatay, Turkey \\ A R T I C L E I N F O

\section{Research Article} \\ Received 10 February 2018 \\ Accepted 09 April 2018

\section{Keywords.} \\ Unio tigridis \\ Age \\ Growth \\ Bivalvia \\ Lake Gölbaşı \\ *Corresponding Author: \\ E-mail: mfatih.can@iste.edu.tr

A B S T R A C T \\ Unio tigridis has an importance for the biodiversity of freshwater ecosystem of the \\ Turkey. However, there is no available literature in the world on the growth of this \\ species yet. The aim of this study, therefore, was to describe the age, growth and \\ mortality of this species living in Lake Gölbaşı from Hatay providence, Turkey. A total \\ 428 of specimen were collected using by divers with hand dredges in depth of 1 to 6 \\ meters based on annual sampling strategy from June- 2004 to May- 2005. Lengths and \\ weighs of sample were ranged as 2.1 to $9.2 \mathrm{~cm}(6.79 \pm 1.52)$ and 1.1 to $73.05 \mathrm{~g}(34.18 \pm$ \\ 15.56), respectively. Weight-Length relationship of all specimens was described as \\ $W=0.193 L^{2.63}\left(R^{2}=0.94\right)$. Thus, a negative allometric growth was detected in the sampled \\ population. The age of each individual was determined by counting the external shall \\ annuli-growth interruption lines. The sampled population was composed of 18 age \\ classes. Specimen belong to age class 7 was the most presented with 20.33 percent in the \\ population. The rate of male to female (m:f) was 0.91:1. Seasonalized von Bertalanffy \\ growth model (SVBGM) was used to describe the growth. From these results, it was \\ shown that seasonality in growth does not occur in this lake for this species $\left(\mathrm{L}_{\infty}=8.80\right.$ \\ $\mathrm{cm}$ (Shell Length), $\mathrm{K}=0.271$ year $^{-1}, \mathrm{t}_{0}=-0.161$ year, $\mathrm{C}=0.014$, $\mathrm{ts}=0.100$ year with RSS \\ $=23.22)$. The total mortality rate $(\mathrm{Z} \pm \mathrm{Se})$ was calculated as $0.401 \pm 0.015$ year $^{-1}$ with $\mathrm{R}$ - \\ square $=0.99\left(\mathrm{CL}\right.$ of $\mathrm{Z}$ with $\left.95 \%=0.361-0.440 \mathrm{year}^{-1}\right)$. Although, there is no fishing, \\ no pollution and no predation risk on this species yet, due to growth characteristic, high $\mathrm{K}$ \\ and low $\mathrm{L}_{\infty}$, this type of species are vulnerable to extinction.
}

DOI: https://doi.org/10.24925/turjaf.v6i5.613-617.1845

\section{Introduction}

Gastropoda and bivalvia are common in the macrobenthic fauna of the aquatic ecosystems. These two groups are important in the trophic level of the aquatic ecosystems as well as, due to their filtering capacities; they are great significance in the self purification of waters (Öktener, 2004; Weber, 2005). As a valuable supplemental food source for humans, freshwater mussels have also important in some areas (McMahon, 1991).

Turkey has some freshwater mussels species in its territorial (Modell, 1951; Geldiay and Bilgin, 1969; Schütt 1983). Among these species, Unio tigridis (Bourguignat, 1852), Unionidae has an importance for the biodiversity of freshwater ecosystem of the Turkey (Schütt, 1983; Şereflişan, 2003; Şereflişan, 2008). Even though the distribution and reproduction biology of this species were reported (Öktener, 2004; Al-Mahdawi and Al-Dulaimi, 2004), there have been no available literatures on the age, growth and mortality of this species yet.
Growth studies are essential instruments in the management of fisheries resources since, they contribute to estimate important parameters of the aquatic populations, such as production, stock size, recruitment and mortality. The aim of this study, therefore, was to describe the age and growth and mortality of this species living in Lake Gölbaşı from Hatay providence, Turkey. Although there has not been any fishing activity on this species yet, this study would get base information in terms of mussel conservation for future.

\section{Materials and Methods}

Study Site

Study was carried out in Lake Gölbaşı, Hatay, Southern Turkey, between June-2004 and May-2005 (36 ${ }^{\circ}$ $30^{\prime} 16^{\prime \prime} \mathrm{N} ; 36^{\circ} 29^{\prime} 42^{\prime \prime}$ E). Lake Gölbaş1 is located in the eastern Mediterranean region of Turkey, $50 \mathrm{~km}$ north of the city of Antakya $\left(36^{\circ} 29^{\prime} \mathrm{E}, 36^{\circ} 30^{\prime} \mathrm{N}\right)$. The lake is a 
natural lake with a surface area of $12 \mathrm{~km}^{2}$ and altitude of $80 \mathrm{~m}$. The volume of the lake is $8 \times 106 \mathrm{~m}^{3}$ with a maximum depth of $6 \mathrm{~m}$. Since it supplies water to the surrounding cotton fields; the water level is being lower in spring and summer. The lake has no incoming or outgoing creeks and is only fed by spring water.

\section{Sampling}

Samples were collected using by divers with hand dredges in depth of 1 to 6 meters based on annual sampling strategy from June- 2004 to May- 2005.

\section{Age and Growth:}

The shell lengths (L) of sampled specimen were measured with vernier calipers to the nearest $0.1 \mathrm{~mm}$ (Hoggarth, 1999) and also, wet weight (W) (to nearest $0.01 \mathrm{~g}$ ) of these specimen were recorded. $\mathrm{L}-\mathrm{W}$ pairs were first plotted in order to identify and delete obvious outliers. Length-weight relationships were estimated by fitting an exponential curve, $\mathrm{W}=\mathrm{aL}^{\mathrm{b}}$, to the data. All calculations were made in MS Excel.

Age can be determined in three ways: size-frequency distribution, release-recovery experiments, and growth interruption lines. Among this methods, the most commonly used technique for age determination is counting the external shall annuli-growth interruption lines (Aldridge, 1999). In this study, therefore, the age of each individual was determined using counting the external shall annuli-growth interruption lines (Richardson, 1987).

In general, the growth of bivalves is adequately described by the von Bertalanffy growth model (VBGM). Especially in freshwater systems, differences in growth rate within a year are sometimes so marked that modifications are required to growth models so that seasonal variation can be described adequately (Haddon, 2001). Various authors, therefore, have presented models that extend the original VBGM to express seasonal variations in growth. Among these models, the seasonalized von Bertalanffy growth model (SVBGM) has been widely accepted, primarily because its additional parameters can be interpreted biologically (Vakily, 1992). Therefore, we used seasonalized von Bertalanffy growth model (SVBGM) to describe the growth of $U$. tigridis as follows:

\section{$L_{t}=L_{\infty}\left\{1-\exp \left[-K\left(t-t_{0}\right)+(C K / 2 \pi) \sin \pi\left(t-t_{s}\right)(C K / 2 \pi) \sin \pi\left(t_{0}-t_{s}\right)\right]\right\}$}

Where $L_{t}$ is the shell length at age $t, L_{\infty}$ is the asymptotic average maximum shell size, $\mathrm{K}$ is a growth rate coefficient that determines how quickly the maximum is attained, $t_{0}$ is the hypothetical age at which the species has zero shell length, and $\mathrm{C}$ is related to magnitude of the oscillations above and below the nonseasonal growth curve. In this model, if $\mathrm{C}=0$, then seasonality is not considered. If $\mathrm{C}=0.5$, then the seasonal growth oscillations are such that growth is increased by $50 \%$ at the peak of the 'growth season', i.e., in 'summer', and, briefly, reduced by $50 \%$ in 'winter'. If $\mathrm{C}=1$, then growth increases by $100 \%$ i.e., doubles during 'summer', and becomes zero in the depth of 'winter'. The parameter $\mathrm{t}_{\mathrm{s}}$ is the time between $\mathrm{t}=0$ and the start of a growth oscillation (Vakily, 1992). The parameters of the SVBGM were estimated using by maximum likelihood method with solver routine built in Microsoft Excel. The performance of the model was assessed, in terms of how well the model fitted the length-at-age data set, by visual inspection of the fitted lines and by sum of squared residuals (RSS values).

\section{Sex Determination}

The sex of each specimen was identified by examining the visceral mass. In the middle portion of the inner demibranchs of the females the interlamellar septa were distinctly thickened to provide structural support for the developing young (Jupiter and Byrne, 1997). This was a permanent feature and in non-brooding specimens facilitated identification of females.

\section{Mortality Rates}

Catch-curve method was used to estimate the total instantaneous mortality rate $(\mathrm{Z})$ based on actual agenumber of specimen at each age data. The total instantaneous mortality rate $(\mathrm{Z})$ composes of fishing $(\mathrm{F})$ and natural mortality $(\mathrm{M})$ rates. Therefore, algebraically, $\mathrm{Z}=\mathrm{F}+\mathrm{M}$ (King, 1996). There is no any fishing pressure $(\mathrm{F}=0)$ on the mussel stock in the lake yet, so inevitably, $\mathrm{Z}=\mathrm{M}$.

Temperature, dissolved oxygen and $\mathrm{pH}$ of the water during the studied period were also determined on the monthly scale.

\section{Results and Discussion}

A total 428 of specimen were analyzed. Lengths and weighs of sample were ranged as 2.1 to $9.2 \mathrm{~cm}(6.79 \pm$ $1.52)$ and 1.1 to $73.05 \mathrm{~g}(34.18 \pm 15.56)$, respectively.

Length-weight relationship of all specimens was described as $W=0.193 L^{2.63}$ (R-square $\left.=0.94\right)$. Confidant limits of " $b$ " coefficient in the W-L relationship were 2.56 to 2.69. A negative allometric growth, therefore, was detected in the sampled population.

According to the Wilbur and Owen (1964), the values of equilibrium constant $b$ lies between 2.4 and 4.5 in most of the bivalves. In India, from the river Kempuhole, the relationship between length-total weight for freshwater bivalve, Parreysia corrugate, was $\mathrm{W}=0.0003428 \mathrm{~L}^{2.777}$ and the monthly equilibrium constant values of lengthtotal weight relationships ranged from 2.606 to 2.945 (Ramesha and Thippeswamy, 2009). For swan mussel, Anodonta cygnea, the length-weight relationship was estimated as $\mathrm{W}=0.00018 \mathrm{~L}^{2.8849}$ (Başçınar, et al., 2009). Variation in growth is determined mostly by environmental differences and population density. In studied area, there is no fishing activity on this population and also no pollution in the lake. Therefore, the most likely reason showing the allometric growth of this species may population density. The population density (We observed that the density of mussel was about 60100 species per $\mathrm{m}^{2}$ ) may have been reached, or nearly, the carrying capacity of the lake ecosystem.

The sampled population was composed of 18 age classes. Among the age classes, the specimen belong to age class 7 was the most presented with 20.33 percent in the population (Table 2 ). 
Table 1 Some water properties (mean \pm Sd) of the lake Gölbaşı between June-2004 and May-2005.

\begin{tabular}{l|ccc}
\hline \multicolumn{1}{c|}{ Month } & Temperature $\left({ }^{\circ} \mathrm{C}\right)$ & Dissolved Oxygen $(\mathrm{mg} / \mathrm{ml})$ & $\mathrm{pH}$ \\
\hline June & $28.44 \pm 0.10$ & $6.31 \pm 0.02$ & $7.93 \pm 0.02$ \\
July & $30.91 \pm 0.06$ & $6.15 \pm 0.05$ & $8.20 \pm 0.03$ \\
August & $33.63 \pm 0.10$ & $5.90 \pm 0.03$ & $8.45 \pm 0.04$ \\
September & $28.84 \pm 0.12$ & $6.47 \pm 0.04$ & $8.31 \pm 0.04$ \\
October & $24.56 \pm 0.15$ & $4.51 \pm 0.12$ & $8.08 \pm 0.01$ \\
November & $17.17 \pm 0.07$ & $9.60 \pm 0.65$ & $8.05 \pm 0.01$ \\
December & $13.13 \pm 0.12$ & $9.58 \pm 0.81$ & $7.89 \pm 0.02$ \\
January & $10.59 \pm 0.16$ & $9.42 \pm 0.55$ & $7.63 \pm 0.02$ \\
February & $13.46 \pm 0.18$ & $8.65 \pm 0.28$ & $7.73 \pm 0.02$ \\
March & $17.57 \pm 0.10$ & $8.25 \pm 0.09$ & $7.72 \pm 0.02$ \\
April & $21.61 \pm 0.07$ & $7.46 \pm 0.11$ & $7.76 \pm 0.03$ \\
May & $22.54 \pm 0.08$ & $6.70 \pm 0.05$ & $7.78 \pm 0.04$ \\
Overall Mean & $21.87 \pm 0.10$ & $7.41 \pm 0.23$ & $7.96 \pm 0.02$ \\
\hline
\end{tabular}

Table 2 Age-length key for $U$. tigridis

\begin{tabular}{|c|c|c|c|c|c|c|c|c|c|c|c|c|c|c|c|c|c|c|c|}
\hline \multirow{2}{*}{$\mathrm{L}$} & \multicolumn{18}{|c|}{ Age } & \multirow{2}{*}{$\mathrm{T}$} \\
\hline & 1 & 2 & 3 & 4 & 5 & 6 & 7 & 8 & 9 & 10 & 11 & 12 & 13 & 14 & 15 & 16 & 17 & 20 & \\
\hline $2.0-2.5$ & 4 & & & & & & & & & & & & & & & & & & 4 \\
\hline $2.5-3.0$ & 6 & & & & & & & & & & & & & & & & & & 6 \\
\hline $3.0-3.5$ & & 5 & & & & & & & & & & & & & & & & & 5 \\
\hline $3.5-4.0$ & & 10 & & & & & & & & & & & & & & & & & 10 \\
\hline $4.0-4.5$ & & 23 & & & & & & & & & & & & & & & & & 23 \\
\hline $4.5-5.0$ & & & 24 & & & & & & & & & & & & & & & & 24 \\
\hline $5.0-5.5$ & & & 12 & & & & & & & & & & & & & & & & 12 \\
\hline $5.5-6.0$ & & & & 9 & & & & & & & & & & & & & & & 9 \\
\hline $6.0-6.5$ & & & & 4 & 6 & & & & & & & & & & & & & & 10 \\
\hline $6.5-7.0$ & & & & & 28 & 7 & & & & & & & & & & & & & 35 \\
\hline $7.0-7.5$ & & & & & & 73 & 34 & & & & & & & & & & & & 107 \\
\hline $7.5-8.0$ & & & & & & 6 & 53 & 50 & 10 & & & & & & & & & & 119 \\
\hline $8.0-8.5$ & & & & & & & & 7 & 14 & 11 & 10 & 5 & 3 & 1 & & & & & 51 \\
\hline $8.5-9.0$ & & & & & & & & & & 3 & & 1 & 2 & 2 & 2 & 1 & & & 11 \\
\hline $9.0-9.5$ & & & & & & & & & & & & & & & & & 1 & 1 & 2 \\
\hline $\mathrm{T}$ & 10 & 38 & 36 & 13 & 34 & 86 & 87 & 57 & 24 & 14 & 10 & 6 & 5 & 3 & 2 & 1 & 1 & 1 & 428 \\
\hline$\%$ & 2.33 & 8.87 & 8.41 & 3.03 & 7.94 & 20.09 & 20.32 & 13.31 & 5.6 & 3.27 & 2.33 & 1.4 & 1.16 & 0.7 & 0.46 & 0.23 & 0.23 & 0.23 & 100 \\
\hline L-mean & 2.46 & 3.97 & 4.86 & 5.86 & 6.66 & 7.22 & 7.55 & 7.82 & 8.07 & 8.21 & 8.11 & 8.31 & 8.41 & 8.53 & 8.91 & 8.97 & 9.1 & 9.2 & 6.83 \\
\hline $\mathrm{W}$-mean & 2.01 & 8.04 & 12.38 & 16.86 & 27.4 & 36.9 & 41.3 & 44.82 & 45.37 & 46.97 & 51.06 & 50 & 48.04 & 47.61 & 50.25 & 67.15 & 48.28 & 55.79 & 33.67 \\
\hline L-std & 0.2 & 0.38 & 0.27 & 0.22 & 0.17 & 0.19 & 0.2 & 0.12 & 0.16 & 0.2 & 0.1 & 0.23 & 0.08 & 0.15 & 0.04 & 0 & 0 & 0 & 1.47 \\
\hline W-std & 0.68 & 2.37 & 2.09 & 1.73 & 5.91 & 7.44 & 7.03 & 7.32 & 8.01 & 6.62 & 5.95 & 6.55 & 10.51 & 15.3 & 1.68 & 0 & 0 & 0 & 15.39 \\
\hline M:Fm & $1: 0$ & $3.25: 1$ & 11:1 & 1.85:1 & $1.33: 1$ & 0.83:1 & $0.59: 1$ & $0.32: 1$ & $0.56: 1$ & $0.22: 1$ & $0.37: 1$ & $0.07: 1$ & $0.2: 1$ & $0: 1$ & $0: 1$ & $0: 1$ & $0: 1$ & $0: 1$ & $0.91: 1$ \\
\hline
\end{tabular}

L: Length, T: Total

The percent of the unsexed, male and female in the population were $4.43,45.56$ and 50 , respectively. Therefore, the rate of male to female (m: f) was $0.91: 1$ $(\mathrm{P}>0.05)$. After the age of 5, however, the rates of male against the female were continuously decreased and after the age of 13, male specimen were not observed (Table 2). Aldridge (1999) analyzed sex ratios of four unionids (A. anatine, A. cygnea, U. pictorum and U. tumidus). $\mathrm{He}$ found that except for A. cygnea, the ratio of male: female was biased slightly to female for the other unionids. Our result (0.91:1), therefore, is consistent with his study.

The parameters of seasonalized von Bertalanffy growth model were presented in Table 3. The coefficient $\mathrm{C}$, reflects seasonality in growth, was close to zero (0.0143). Therefore, it is shown that seasonality in growth does not occur in this lake for this species (Figure 1).

Von Bertalanffy Growth Model (VBGM) has certainly been widely used in marine and freshwater fisheries research, despite considerable argument over its biological value, particularly over the reality of asymptotic growth. Alternative growth models with the VBGM, therefore, have been used to describe the growth in comparative studies (Hastie et al., 2000; Haddon, 2001). Akiyama and Iwakuma (2009), fitted several growth models (Hyperbolic, Gompertz, Logistic and von Bertalanffy growth functions) to the shell length-age relationships for two populations (Shiribetsu river and Chitose river) of a freshwater pearl mussel, Margaritifera laevis (Bivalvia, Unionoida), in northern Japan. They found that the Gompertz function showed the best fit, in terms of both RSS (residual sum of squares) and the difference between the observed maximum shell length and the asymptotic shell length. In the same study, the K values for Shiribetsu and Chitose river populations were estimated as 0.251- 0.305 year-1 and 0.077- 0.097 year ${ }^{-1}$, respectively.

In northern Scotland, the estimated $\mathrm{K}$ values in von Bertalanffy growth model (VBG) ranged $0.023-0.085$ year $^{-1}$ for freshwater pearl mussels (Margaritifera margaritifera). They compared three non-linear growth 
models (power, logistic and von Bertalanffy) and they found that the VBG model outperformed the other two approaches, generating the smallest residuals (Hastie et al., 2000).

Maroñas et al., (2003) estimated K values for different cohorts of the golden mussel, Limnoperna fortune (Dunker, 1857), as 0.3371, 0.3409 and 0.3761 year $^{-1}$. They adjusted the growth models according to the version of the generalized length growth. The best result was obtained applying the VBGM weighted according to the number of specimens at each mode.

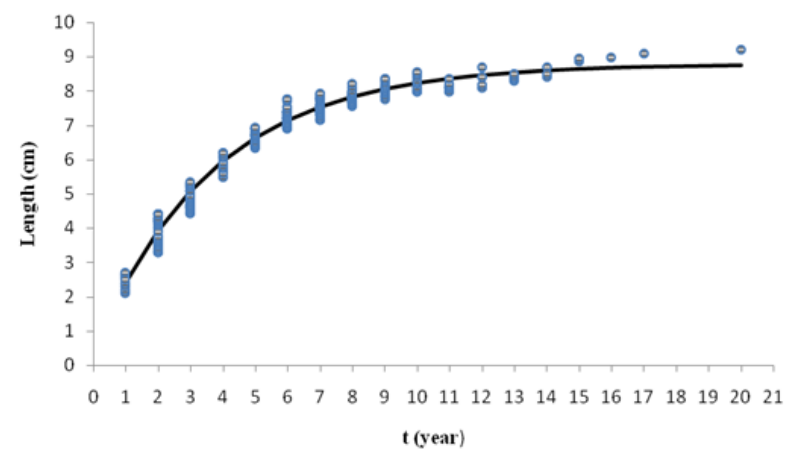

Figure 1 Growth curve of U. tigridis.

Table 3 The parameters of seasonalized von Bertalanffy growth model (SVBGM) for $U$. tigridis.

\begin{tabular}{l|c}
\hline \multicolumn{1}{c|}{ Parameters } & Model (SVBGM) \\
\hline $\mathrm{L}_{\infty}:$ & 8.800 \\
$\mathrm{~K}:$ & 0.271 \\
$\mathrm{t}_{0}:$ & -0.161 \\
$\mathrm{C}:$ & 0.014 \\
$\mathrm{t}_{\mathrm{s}}:$ & 0.100 \\
$\mathrm{RSS}$ & 23.221 \\
\hline
\end{tabular}

Based on the length-at-age data, we estimated the growth parameters of $\mathrm{K}$ and $\mathrm{L}_{\infty}$ as 0.271 year $^{-1}$ and 8.80 $\mathrm{cm}$, respectively. The value of $\mathrm{K}$ from von Bertalanffy growth equation is highly variable depending on environment temperature. It was reported that there was a direct relationship between parameter $\mathrm{K}$ and temperature in unionid mussel and the influence of water temperature on growth to be greater than that of hydrochemistry (Hastie et al., 2000). As the temperature decreases in temperate regions, the metabolic rate also declines hence the rate of growth decreases (Malathi and Thippeswamy, 2013). In our studied environment, the average water temperature was $21.87 \pm 0.10$ Celsius. Therefore, this estimated value $\left(0.217\right.$ year $\left.^{-1}\right)$ for our population is expectable for this environment conditions.

The lake was classified as first-degree clean water (Şereflişan, 2003). In respect to hydrochemistry, Ca content and $\mathrm{pH}$ level are linked and important component on the growth of mussel. It is reported that the minimum $\mathrm{pH}$ level for unionid mussel growth is 4.7 and the $\mathrm{pH}$ range of growing and fertilization is 5.6 to 8.3 . Temperature, dissolved oxygen and $\mathrm{pH}($ mean $\pm \mathrm{Sd})$ of the water are given in Table 1.

Our mean pH levels were changed as 7.72 to 8.45 with the overall mean 7.41 \pm 0.23 (Table 1). McMahon (1991) claimed that generally in an area where pH level is low then calcium concentration is low as well and low calcium levels lead to shell melting for mussel. It was found that asymptotic length $\left(\mathrm{L}_{\infty}\right)$ estimates were positively correlated with biological oxygen demand (BOD) and $\mathrm{pH}$, whereas relative growth rate $(\mathrm{k})$ estimates were negatively correlated with $\mathrm{BOD}, \mathrm{pH}$ and calcium ion concentration (Bauer, 1992; Hastie et al.,2000).

It is reported that the zooplankton of lake Gölbaşı mainly consists of Cladocera (with 27 species), Copepoda (with 2 species) and Rotifera (with 23 species) groups and, based on the eutrophication index value, Lake Gölbaşı has mesotrophic characteristics. (Türkmen et al., 2006). Also, 28 phytoplankton species were identified in the lake (Şereflişan, 2003). Lake Gölbaşı, therefore, can be classified into the mid-productive lake category.

The total instantaneous mortality rate $(Z \pm \mathrm{Se})$ was calculated as $0.401 \pm 0.015$ year $^{-1}$ with $\mathrm{R}$-square $=0.99$ $\left(\mathrm{CL}\right.$ of $\mathrm{Z}=0.361-0.440$ year $\left.^{-1}\right)$. There is no any fishing activity on that stock in this lake yet (therefore, it could be assumed that fishing mortality equal to zero, $F=0$ ). Calculated value of $\mathrm{Z}$, therefore, may just reflection of natural mortality rate $\left(\mathrm{M}=0.401\right.$ year $\left.^{-1}\right)$. There is almost no predation on the mussels in the Lake Gölbaşı. Only a few numbers of crabs was observed in the studied area. The cause of natural mortality, therefore, may mostly due to other factors than predation.

\section{Implication for Conservation}

Irrespective of other factors that effects on mussel shell growth, the growth coefficient in VBG model $(\mathrm{K})$ is negatively correlated with maximum age and maximum length (low $\mathrm{K}$ values tend to high $\mathrm{L}_{\infty}$ values). In other words, population with small, short-lived adults tends to exhibit a relatively higher mean growth rate than those with larger and older individuals. In general, fertility is closely related to maximum length (i.e. $\mathrm{L}_{\infty}$ ), as larger mussels produce more offspring than that of smaller ones. In contrary, populations which are characterized by high $\mathrm{K}$, low $\mathrm{L}_{\infty}$ values are particularly vulnerable to extinction, because of their relatively low overall reproductive output (Hastie et al., 2000).

According to the Bauer $(1991,1992)$ pearl mussel populations which have predominantly small, fast growing, short-lived individuals (i.e. high $\mathrm{K}$ and low $\mathrm{L}_{\max }$ ), are particularly vulnerable to extinction. This is because, the overall reproductive output in these populations is relatively low ( $\mathrm{L}_{\max }$ and $\mathrm{L}_{\infty}$ are closely related to fecundity).

Populations which exhibit a combination of a high individual growth rate $\left(\mathrm{K}>0.1\right.$ year $\left.^{-1}\right)$ and a high juvenile mortality rate (e.g. as a result of organic pollution) are considered to be most at risk of decline. Also, intensive fishing and predation lead to remove most of the largest mussel. The effects of these activities on the average growth curve of a population are unknown, but it is likely that the above presses could significantly increase parameter K (Bauer, 1991).

Although, there is no fishing, no pollution and no predation risk on this species yet, due to growth characteristic, this type of species are vulnerable to extinction. The consumption levels of fish and other sea food products are low comparing to the EU countries (Can et.al. 2015), nearly $5 \mathrm{~kg}$ for per individual per year. In future, however, training and mass advertising 
campaigns along the government subsidies can be useful to diversification of income in rural areas by import. At that time, the fragile characteristic of that mussel stock should be considered for sustainable exploitation.

\section{References}

Akiyama YB, Iwakuma T. 2009. Growth parameters of endangered freshwater pearl mussel (Margaritifera laevis, Unionoida). Fundamental and Applied Limnology / Archiv für Hydrobiologie, 175(4): 295-305.

Aldridge DC. 1999. The morphology, growth and reproduction of Unionidae (Bivalva) in a Fenland waterway. J.Moll.Stud., 65: 47-60.

Al-Mahdawi M, Al-Dulaimi M. 2004. Reproductive bahavior of freshwater clams Unio tigridis (Bou.) and Pseudodontopsis euphraticus (Bou.) in Al- Habbanyah Lake, Iraq. Journal of King Abdul Aziz University Marine Sciences, 15(1): 3-20.

Başçınar NS, Düzgüneş E, Mısır DS, Polat H, Zengin B. 2009. Growth and flesh yield of the swan mussel [Anodonta cygnea (Linnaeus, 1758)] (Bivalvia: Unionidae) in the lake Çıldır (Kars, Turkey). Turkish Journal of Fisheries and Aquatic Sciences, 9: 127-132.

Bauer G. 1991. Plasticity in life history traits of the freshwater pearl mussel. In: Seitz A and Loeschcke W (Eds.), Species Conservation: A population biological approach. Birkhauser Verlag, Basel, pp. 103-120.

Bauer G. 1992. Variation in the life span and size of the freshwater pearl mussel. Journal of Animal Ecology, 61: 425-436.

Can MF, Günlü A, Can HY. 2015. Fish consumption preferences and factors influencing it. Food Science and Technology, 35: 339-346.

Geldiay R, Bilgin FH. 1969. Some Mollusks Species identified from the Different Region of Turkey (in Turkish). Ege University Press (Technical Report No: 190), İzmir, 36 p.

Haddon M. 2001. Modelling and Quantitative Methods in Fisheries. Chapman \& Hall Book, Boca Raton. ISBN: 158488-177-1.

Hastie LC, Young MR, Boon PJ. 2000.Growth characteristics of freashwater paerl mussels, Margaritifera margaritifera (L.). Freshwater Biology, 43: 243-256.

Hoggarth MA. 1999. Description of some of the glochidia of the Unionidae (Mollusca: Bivalvia). Malacologia, 41: 1-118.

Jupiter SD, Byrne M. 1997. Light and scanning electron microscopy of the embryos and glochidia larvae of the Australian freshwater bivalve Hyridella depressa (Hyriidae). Invertebr. Reprod. Dev., 32:177-186.

King M. 1996. Fisheries Biology, Assessment and Management. Fishing New Books, USA, 341p.
Malathi S, Thippeswamy S. 2013. Population ecology of freshwater mussel Parreysia corrugate (Mullar, 1774) from River Malthi, Tributary of river Tunga in the Western Ghats, India. Recent Research in Science and Technology, 5(4): 2026.

Maroñas ME, Darrigran GA, Sendra MR, Breckon G. 2003. Shell growth of the golden mussel, Limnoperna fortune (Dunker, 1857) (Mytilidae), in the Rio de la Palta, Argentina. Hydrobiologia, 495: 41-45.

McMahon RF.1991. Mollusca: Bivalvia. In J.H. Thorp \& A.P.Covich (Eds.), Ecology and classification of North American Freshwater Invertebrates. Academic Press, San Diego, pp. 315-399.

Modell H. 1951. Die najaden vorderasiens (in German with Turkish summary). İstanbul Universitesi Fen Fakültesi Mecmuaları serisi. İstanbul, B16: 351-356.

Öktener A. 2004. A preliminary research on mollusca species of some freshwaters of Sinop and Bafra. G.U. Journal of Science, 17(2): 21-30.

Ramesha MM, Thippeswamy S. 2009. Allometry and condition index in the freshwater bivalve Parreysia corrugata (Müller) from river Kempuhole, India. Asian Fisheries Science, 22: 203-214.

Richardson CA. 1987. Microgrowth bands in the shell of the Malaysian cockle, Anadara granosa, and their use in age determination. J. exp. mar. Biol. Ecol., 11 1: 77-98.

Schütt H. 1983. Die Molluskenfauna der Süßwäser im Einzugsgebiet des Orontes unter Berücksichtigung benachbarter FluBsysteme. Arch. Moll., 17-91: 225-228.

Şereflişan H. 2003. Investigations on reproductive biology and aquaculture potential of Unio terminalis delicatus (Lea, 1863) inhabiting Gölbaşı Lake (Hatay). Ph.D diss., University of Çukurova, Adana, Turkey.

Şereflişan H. 2008. The status and economical examination of shell industry based on freshwater bivalves of the world in Turkey. II. National Malacology Congress. 8-10 October 2008, p. 215-219, Adana, Turkey.

Türkmen M, Naz M, Dinler ZM. 2006. The species composition and biomass of zooplankton in Lake Gölbaşı (Hatay, Turkey) (in Turkish). Ege University Journal of Fisheries \& Aquatic Sciences, 23 (1/1):163-167.

Vakily JM. 1992. Determination and comparison of bivalve growth, with emphasis on Thailand and other tropical areas. Technical Report No. 36, ICLARM, pp. +125 .

Weber E. 2005. Population size and structure of the tree mussel species (Bivalvia: Unionidae) in a northeastern German river with special regard to influences of environmental factors. Hydrobiologia, 537(1-3): 169-183.

Wilbur KM, Owen G. 1964. Growth. Physiology of Mollusca Vol 1, Academic, New York, pp.+211. 